\title{
Grace: \\ A virtual recreation of the Grace Darling story
}

\author{
Sophie Dixon \\ Mnemoscene \\ Brighton, UK \\ sophie@mnemoscene.io
}

\begin{abstract}
This paper examines Grace, a computer-generated film created for the Grace Darling Museum, Northumberland, UK. Commissioned in 2019, the initial concept was to create an installation, which gives the museum's visitors a new perspective on the story of Grace Darling's life. In 1838, Grace Darling became one of the greatest female celebrities of the Victorian era. After rescuing survivors from the wreck of the SS Forfarshire, her quiet life as a lighthouse keeper's daughter was changed forever, as she became an internationally celebrated heroine. She died just a few years later, aged twenty-six, from tuberculosis. Throughout this paper, the treatment and process behind Grace are explored. These include the 3D recreation of Grace Darling's family home in Longstone Lighthouse, storytelling using museum and archival collections, and computer-generated filmmaking.
\end{abstract}

Museums and collections. Computer-generated imagery. Memory. Place. Photogrammetry. Film.

\section{INTRODUCTION}

In the early hours of September 7th, 1838, from her bedroom window in Longstone Lighthouse, Grace Darling sighted the wreck of the SS Forfarshire.

The paddle steamer, which had run aground, was carrying around forty passengers alongside the crew (Darling 1880). The surviving passengers had sought safety on the 'Big Harcar' rock, which lies half a sea mile from Grace Darling's lighthouse home in the Farne Islands. Together with her father, she rowed their sixteen-foot coble through rough seas to the rock, saving the lives of nine people.

Grace Darling was a twenty-three-year-old daughter of a lighthouse keeper. For her act of bravery, 'unexampled in the feats of female fortitude', she was hailed as a heroine (Cunningham 2007). Grace Darling, the heroine, rapidly became a celebrity, and visitors would make the journey to her remote lighthouse home to request her signature, locks of hair, and snippets of clothing.

Furthermore, artists also visited the lighthouse to capture her likeness. Across the numerous paintings, no two images appear to portray the same person. The fluidity of Grace Darling's appearance and story is indicative of the ever-changing interpretation of her personality throughout history. The story of Grace Darling has made its way into plays, songs, books, and films. Across these interpretations, it is challenging to develop a clear idea of who she was or to imagine her side of the story. Hugh Cunningham (2007) describes Grace Darling as a lieux de memoire, or a realm of memory, in which her symbolic status, with its capacity to metamorphose, is likely to mean different things to different generations.

While Grace Darling's written correspondence to her admirers is courteous, there are accounts through which the pressure of her celebrity status becomes evident. Her father writes:

You can hardly form an idea how disagreeable it is to my daughter to show herself in publick. (Armstrong 1965)

This presents a stark contrast between the personal life of a young woman and the public persona she unwittingly became.

On October 20th, 1842, in the midst of her fame, Grace Darling died of tuberculosis. Aged just twentysix, the impression of beauty and innocence that had been constructed around her was, therefore, eternally preserved.

In the years after her death, her closest sister, Thomasin, wrote the book Grace Darling, Her True Story to set the narrative straight. It is through this book, which includes Grace Darling's personal 
correspondence, that we get, perhaps, the closest to her true character. Thomasin, through her writing, describes a humble young woman:

Grace never thought the world owed her anything, she never thought of herself in relation to her deed, the trouble was the world thought of little else. (Darling 1880)

This sentence, which also opens Grace, serves as a reminder that among the many ways we remember Grace Darling, it is her life as an ordinary young woman that is, perhaps, most easily forgotten.

The RNLI Grace Darling Museum in Bamburgh, Northumberland, stands next to the house in which Grace Darling was born and overlooks her ornate grave in St Aidan's churchyard. The museum's collection includes objects from her family home, memorabilia, and paintings, as well as the Darling family's coble.

The aim of commissioning Grace, facilitated by the organisation Arts and Heritage, was to create an artistic response for the Grace Darling Museum. Its primary challenge became to navigate the aforementioned nuances of Grace Darling's story.

\section{APPROACH}

The initial proposal was to create an immersive experience providing a fresh perspective to the story of Grace Darling, which would also incorporate digitised items from the museum's collection.

The early-stage design process included a workshop with volunteers, held in September 2019 at the Grace Darling Museum. At that meeting, a chronological timeline of Grace Darling's life was established that included key events, such as moments from her childhood, the night of the rescue, her subsequent fame, and her death.

Participants were asked to consider objects which may represent, or be associated with, these events. Many of the objects discussed came from the museum's collection. For example, her wooden cot and books were associated with her childhood, whereas various pieces of wreckage from the SS Forfarshire were related to the night of the rescue. Paintings and a marble bust were associated with her subsequent fame. Alongside objects held in the museum, additional items were mentioned, such as Grace's father's violin, her eggshell collection, and embroidery.

A number of key locations were identified during the early stages of the research. These included the house in which Grace was born; her grave at St

Aidan's Church; the lighthouse on nearby Brownsman Island, where she lived until the age of eleven; and Longstone Lighthouse, where she resided until her death.

Built in 1826, Longstone Lighthouse is located in the Outer Farne Islands, off the coast of Northumberland. The islands form a nature reserve, currently owned by The National Trust, and are home to thousands of grey seals and seabirds.

Today, the lighthouse is largely empty, with a small display dedicated to Grace Darling on the lower floor. The otherwise isolated outcrop is a thriving seal colony and, in warmer months, a home to a large number of seabirds. As part of the research, an initial visit was made to the lighthouse, during which a 360-degree camera was used to capture each room in detail.

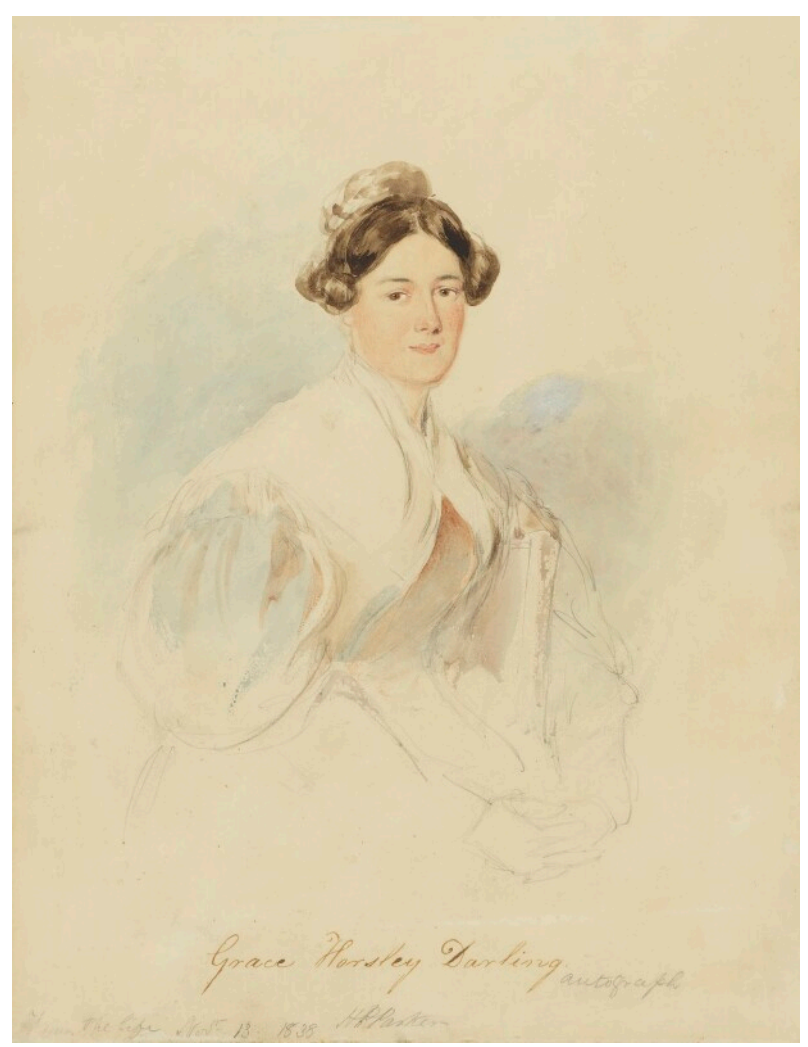

Figure 1: Painting of Grace Darling by Henry Perlee Parker. Watercolour and pencil, 1838. 


\section{TREATMENT}

Depictions of Grace Darling, the heroine, are often extraordinary. In paintings and stories, we see, and hear of, her bravely rowing a coble with the 'streaming, windblown hair of legend' (Mitford 1989). In paintings, she sits poised in her finest clothes, and through detailed written descriptions, we can read about her figure, her face, and her character (Cunningham 2007).

From the outset, this project was designed to provide an experience of Grace Darling's story from a first-person perspective. It was decided that the camera would move through her home, and in doing so, move the viewer through a chronological sequence of key events in her life. The viewer, entering into the lighthouse at dawn, moves through the main room, and in turn, her childhood. From there, they move to her bedroom, which denotes the night of the rescue, and upwards to the top room, which is representative of her overwhelming experience with fame. Finally, the viewer moves around the lighthouse light, a metaphor for the media's spotlight, before leaving the lighthouse by rising into the, now dark, night sky. Within the past timeframe of the narrative, there is a deeper past in which the night of the rescue is recalled. To distinguish this event, a memory within a memory, a projection of the coble from a first-person perspective is cast upon the bedroom wall.
The story of Grace Darling is one that, as discussed earlier, has the ability to metamorphose. Recognising that the story spans almost two centuries of remembrance, the narrative treatment seeks to weave together the key events of her story whilst leaving space for interpretation.

The script for Grace was created using letters and newspaper reports sourced from existing literature and the Northumberland Archives. It includes the voices of Grace Darling, her family, and the public. Her sister Thomasin, perhaps the most careful guardian of her story, is given the first and the final words.

Listening to these first-person accounts, we are looking back and reflecting on events in the past. The time period depicted is after Grace Darling's death, which is still recent enough that her bed is unmade, and traces of her presence linger throughout.

An original film score was composed to interlace recordings of these voices, an environmental soundscape, and traditional folk music. Grace Darling's father, a competent violinist, wrote down many traditional folk tunes, including his own compositions. To fill the lighthouse once again with his music, these songs, recorded within a handwritten music book held at the Grace Darling Museum, were used to form the basis of the score.

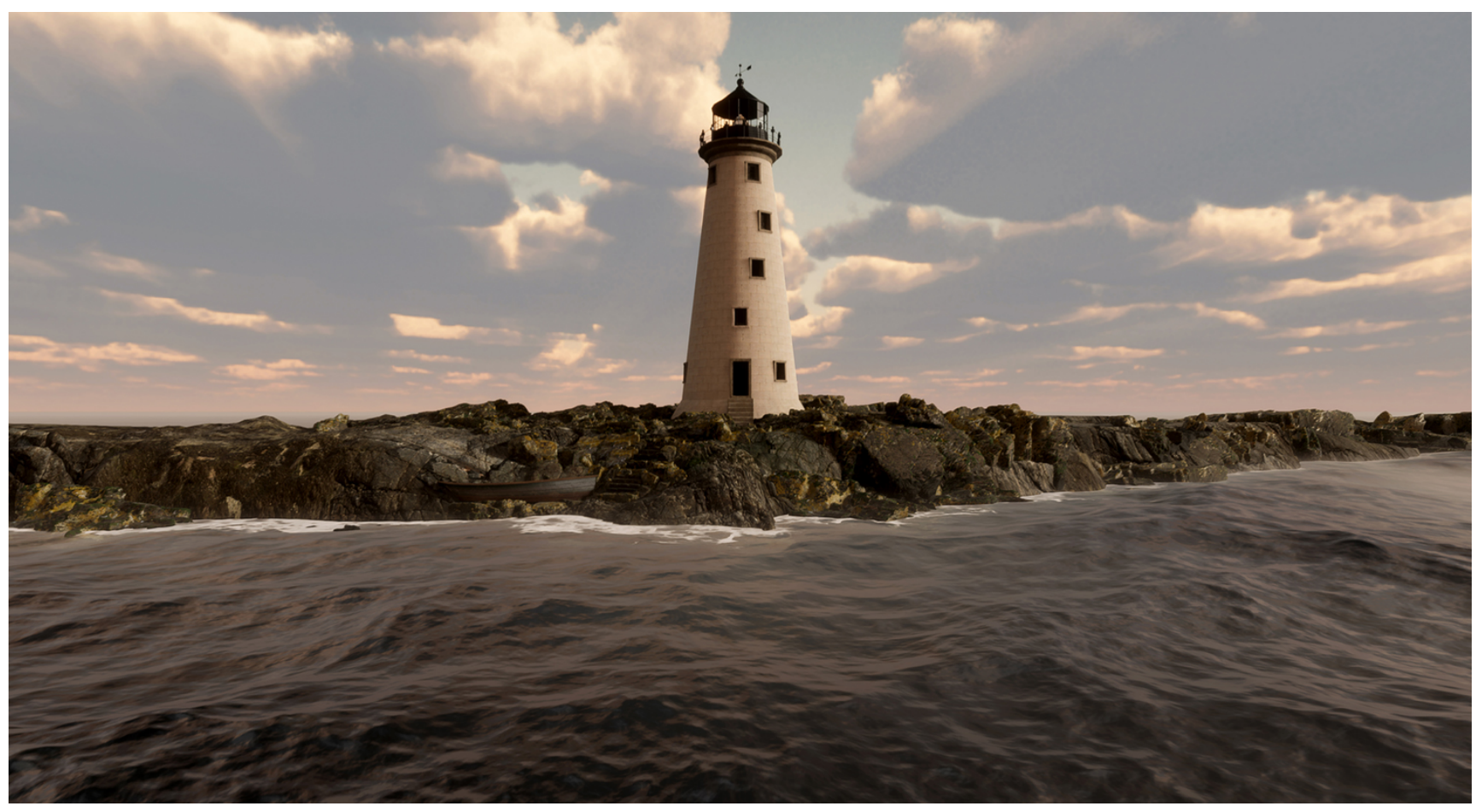

Figure 2: A still from Grace showing the exterior of Longstone Lighthouse at dawn. 


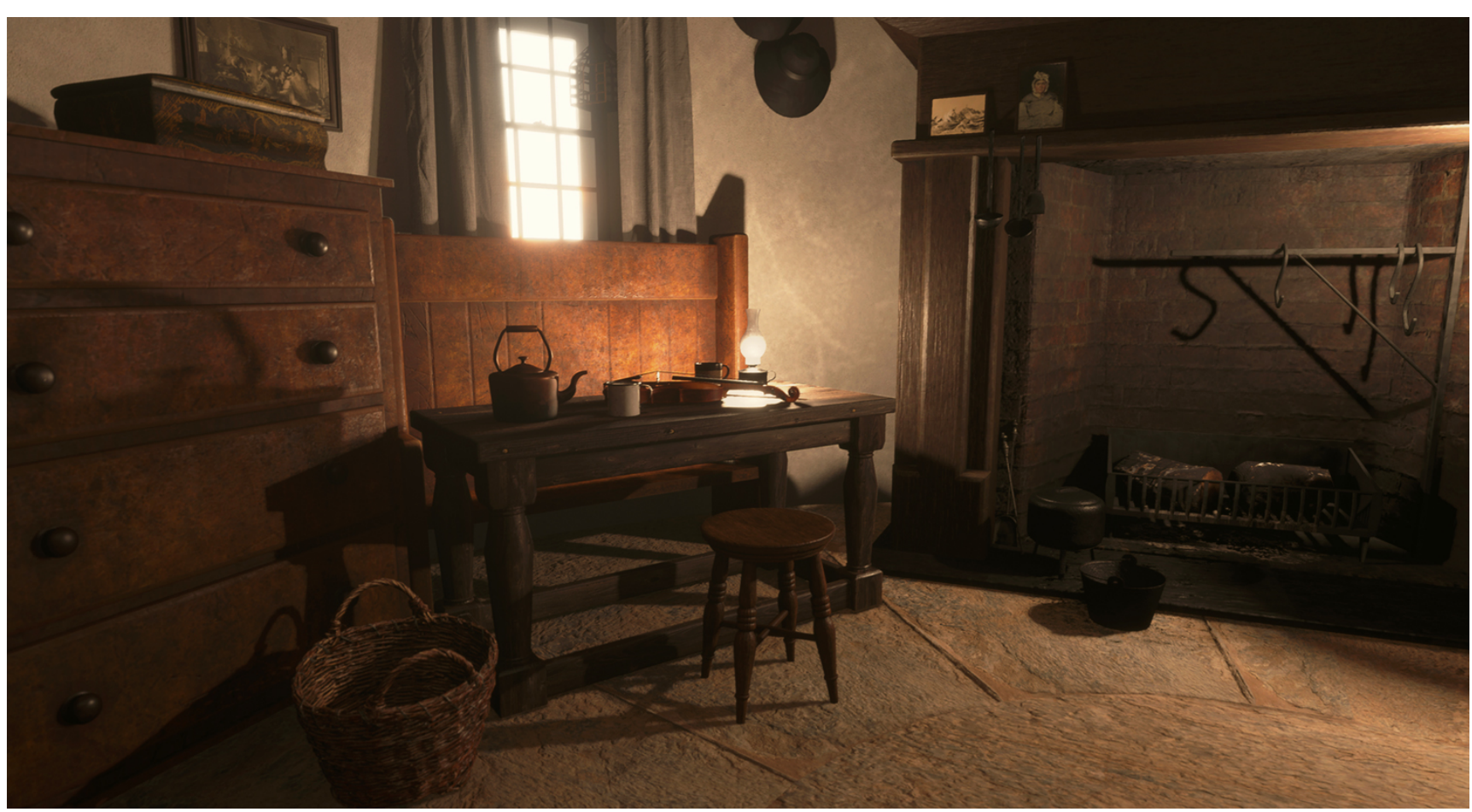

Figure 3: A still from Grace showing the main living area in Longstone Lighthouse.

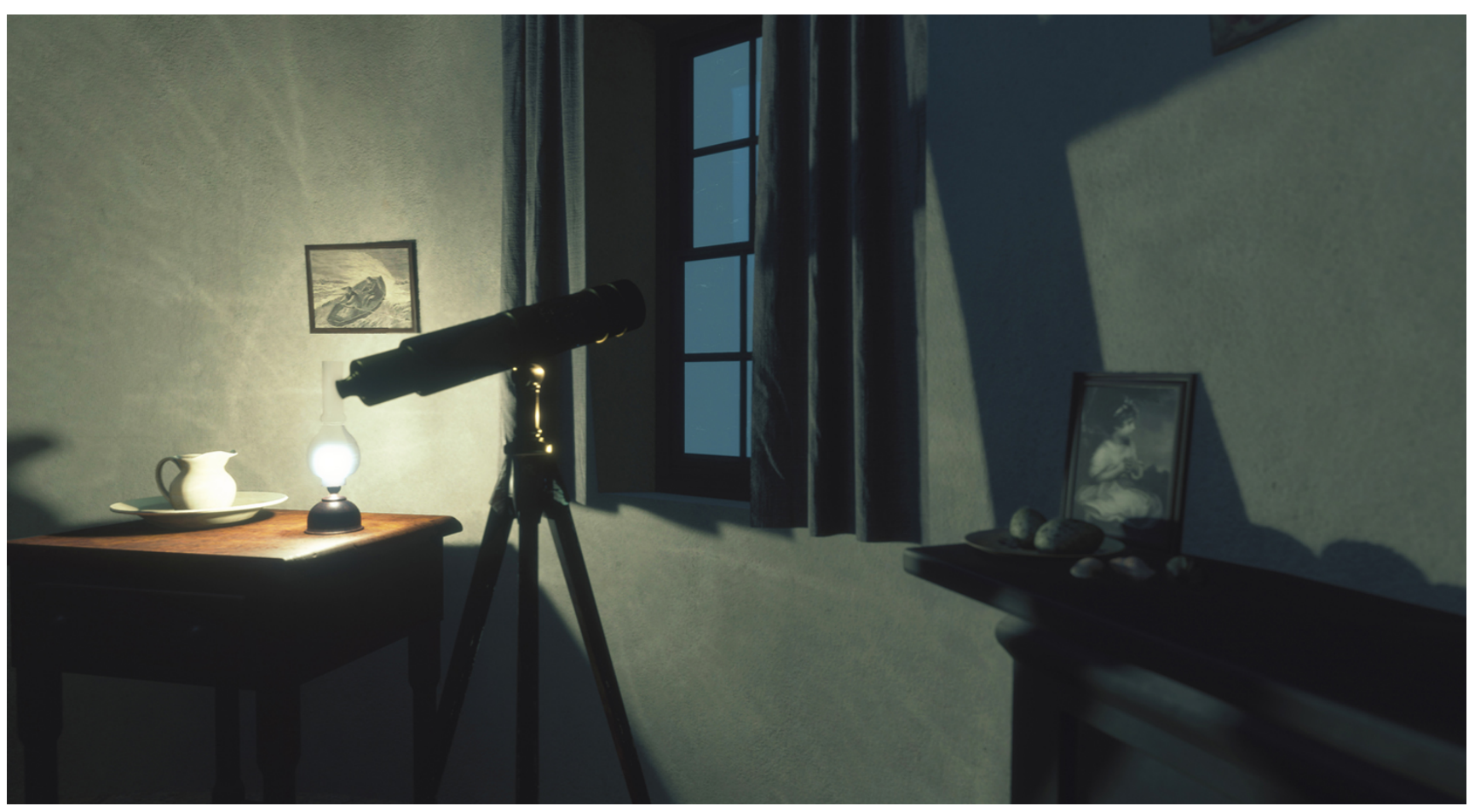

Figure 4: A still from Grace showing the bedroom window from which she first sighted the SS Forfarshire. 


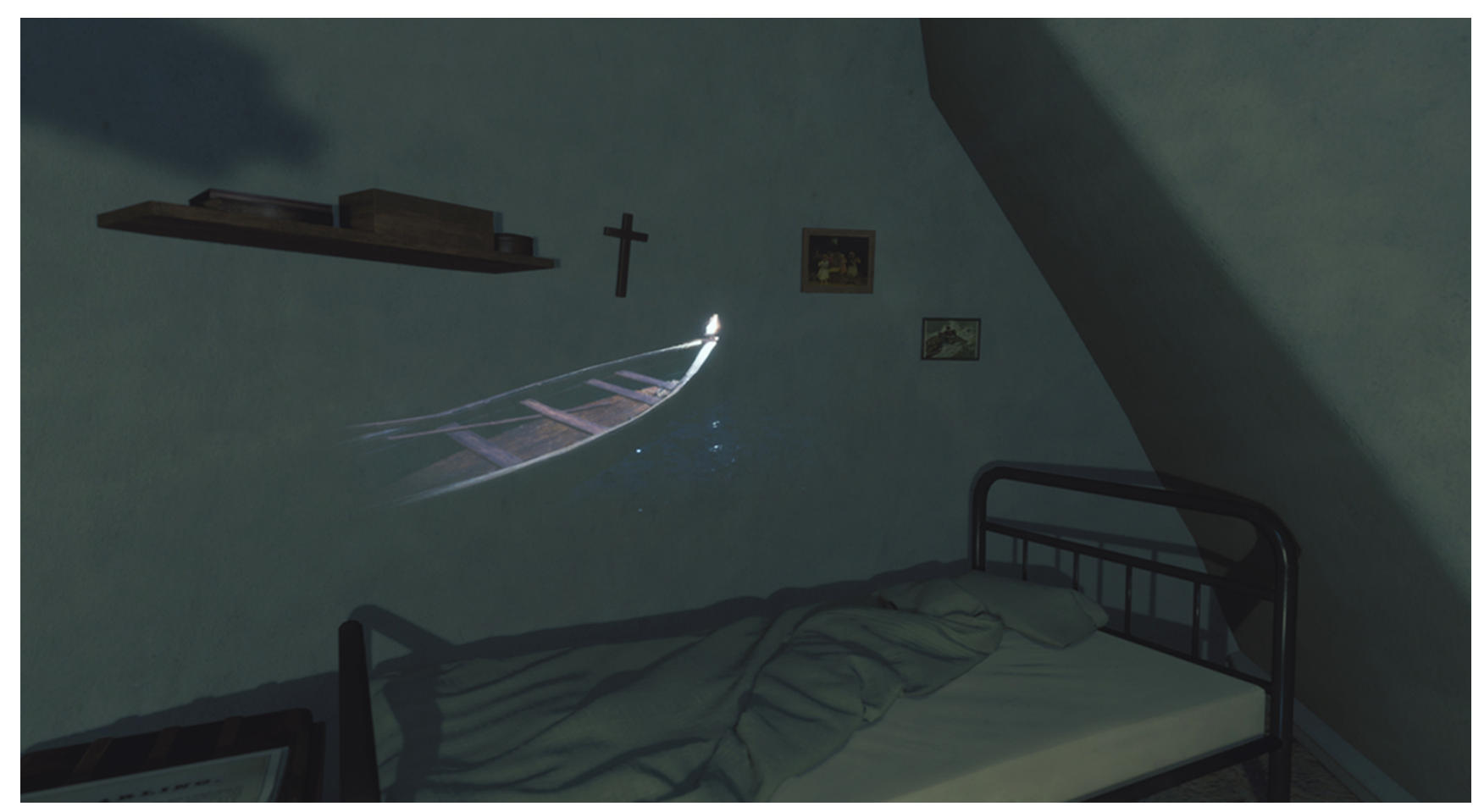

Figure 5: A still from Grace showing the projection on her bedroom wall in Longstone Lighthouse.

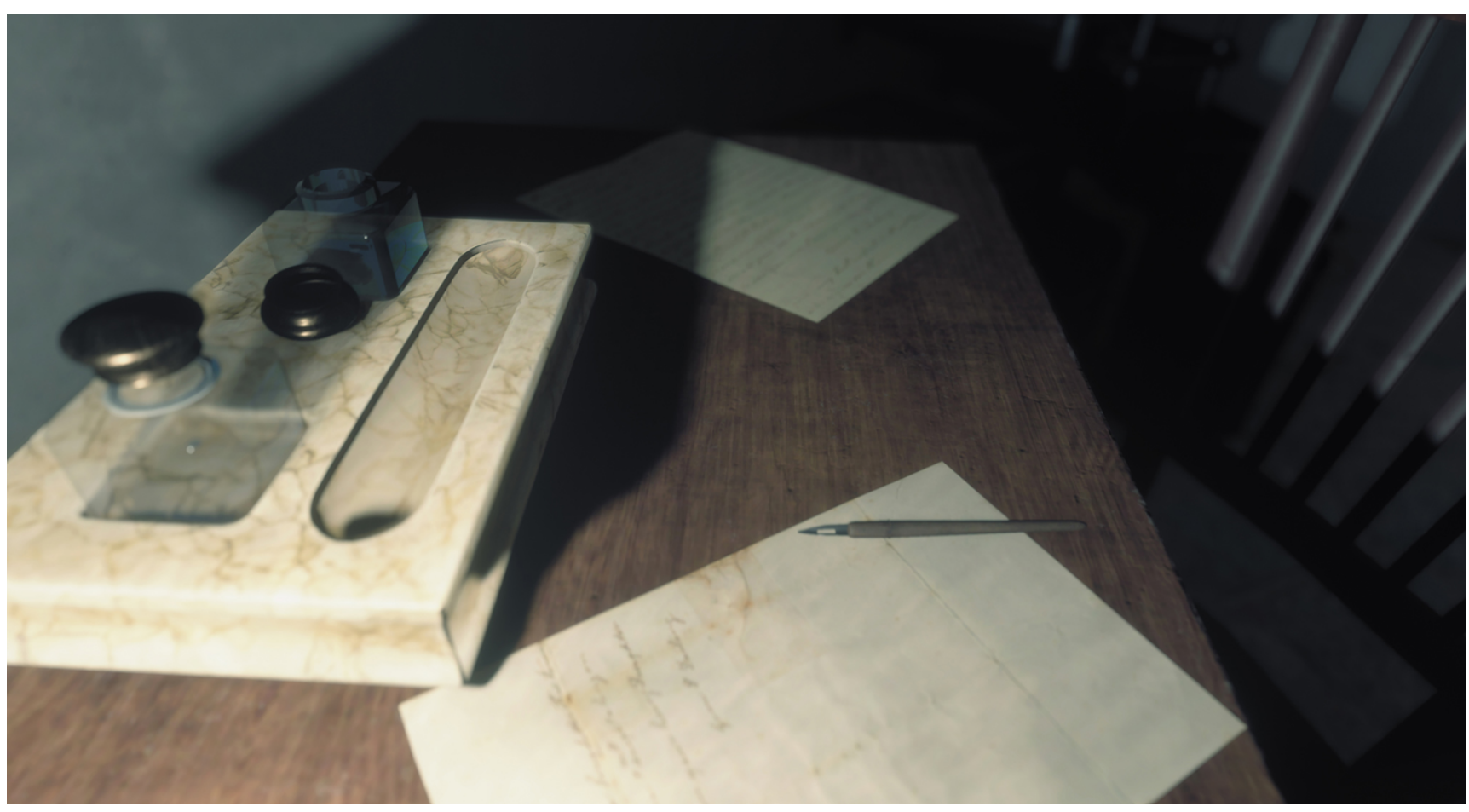

Figure 6: A still from Grace showing Grace Darling's writing desk. 

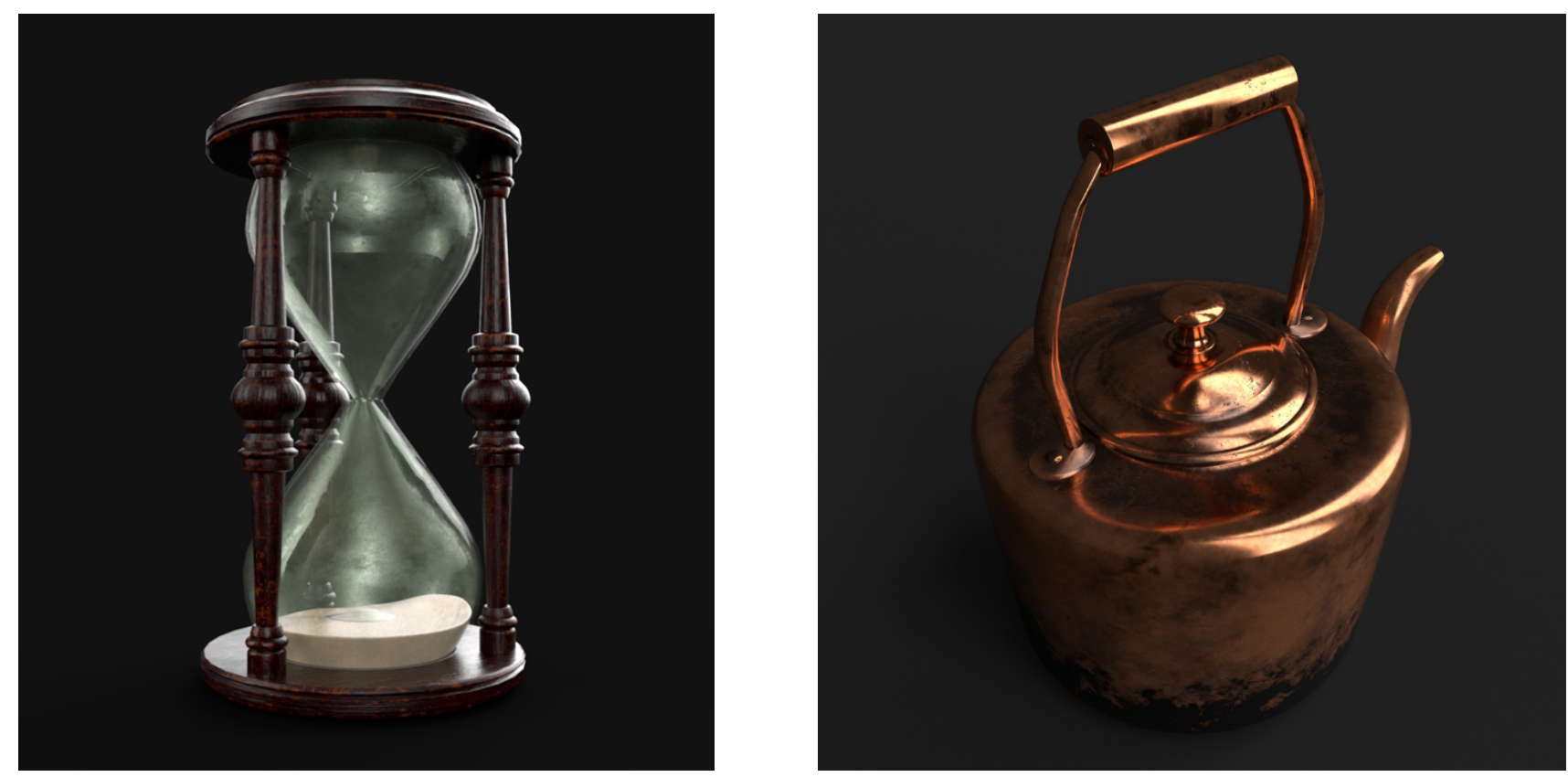

Figure 7: Assets from Grace modelled from reference images.

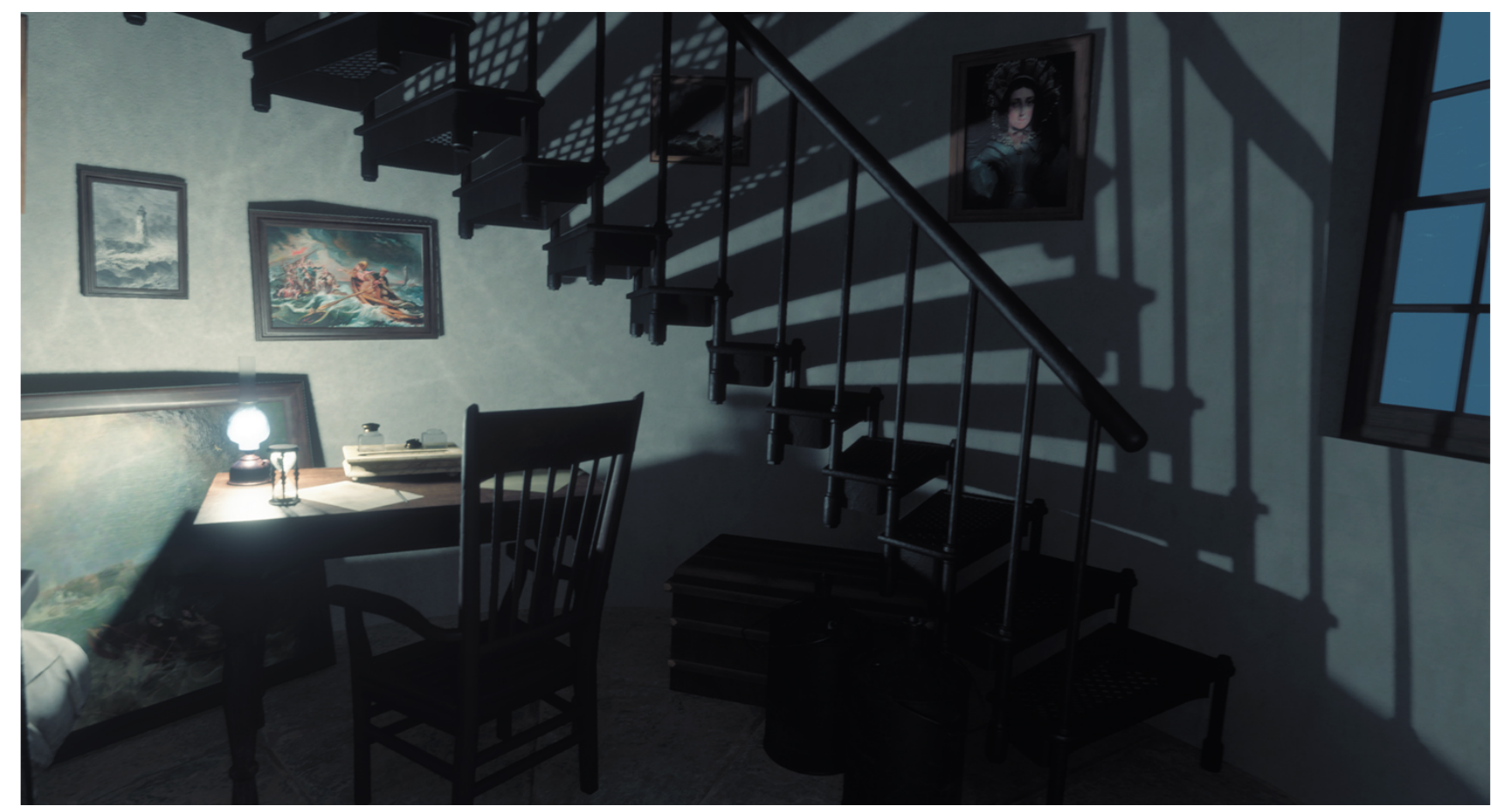

Figure 8: A still from Grace showing the top room of the lighthouse and stairs to the lantern room. 


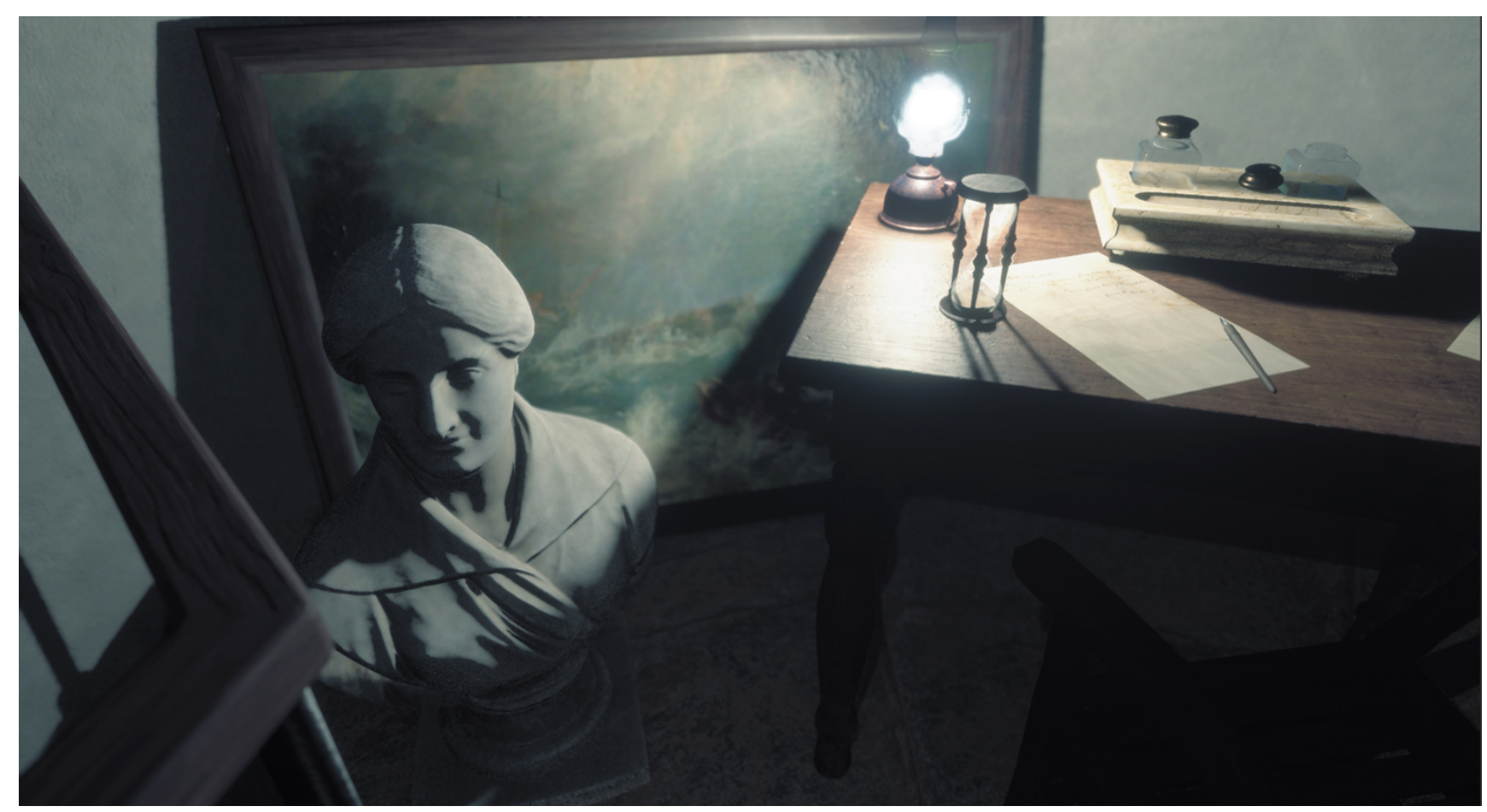

Figure 9: A still from Grace showing a photogrammetry model created from D. Dunbar's sculpture of Grace Darling.

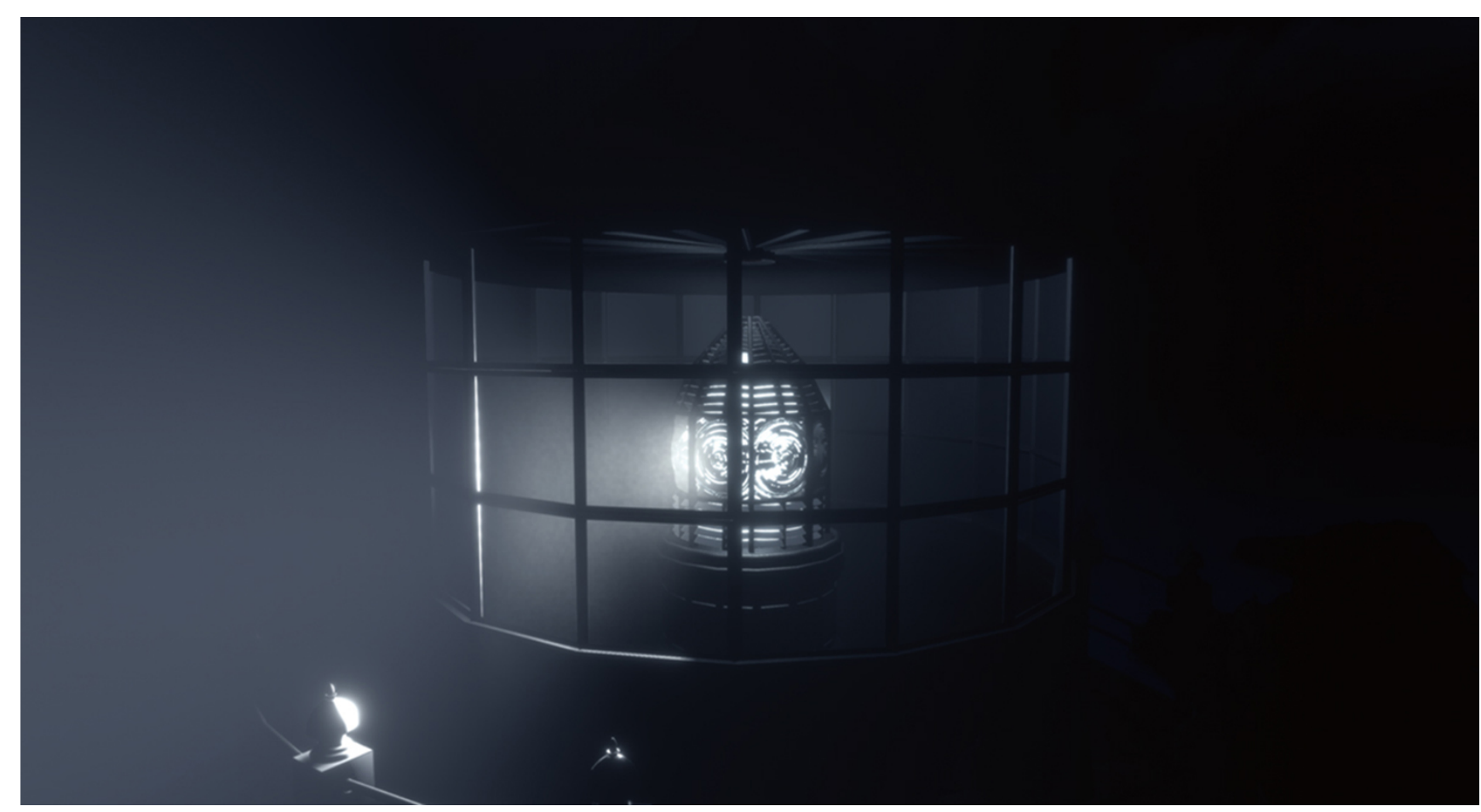

Figure 10: A still from Grace showing the exterior of Longstone Lighthouse at night. 


\section{RECREATION}

The recreation of Longstone Lighthouse involved a detailed research stage, digitisation of 3D objects, $3 \mathrm{D}$ modelling, and the creation of an environment within a game engine.

There are limited sources that show how the interior of Grace Darling's home in the lighthouse would have looked. One image, an engraving by H. P. Parker, which shows the main living room on the night of the rescue, was used as a reference. Other areas of the lighthouse were recreated based on comparable living spaces from that period.

A key aim throughout the recreation process was to preserve a degree of historical accuracy. Panoramic images of the lighthouse interior were used for reference together with original floor plans obtained from The Trinity House Archives. The lighthouse has gone through significant changes since its construction in 1826. These include the additions of living quarters to the side of the lighthouse and red and white paint to the exterior. The recreation focused specifically on the period of Grace's life, until just after her death (1815-1845).

Based on the objects identified in early workshops, a number of items from the museum's collection were digitised using photogrammetry. These included Grace Darling's childhood cradle; a marble bust of her, sculpted by the artist David Dunbar; and a wooden sewing box, gifted to her by a member of the public. Photogrammetry is a scientific way of taking spatial measurements from photographs. Using purpose-built software digital photographs of a physical object can be used to create a precise digital 3D replica. This process is an effective method for creating highly realistic models of heritage objects. However, recognising that not all objects would be suitable candidates for photogrammetry, a large number of photos were also taken of other items within the collection as a reference for $3 D$ modelling.

The completed model of Longstone Lighthouse was integrated into a game engine. Using this, physically-based lighting, terrain, ocean renderer, and post-processing were added to the scene to create a realistic environment. Lighting and postprocessing were also used to adjust the colours of the environment, changing them from warm to cooler colours as the narrative progresses.

\section{REALISATION}

Grace was realised as a computer-generated short film to be shown as either a single-screen film or a multi-screen installation. The multi-screen installation is designed for greater immersion, giving the viewer different perspectives upon the same scene. It consists of the primary central screen, supported by two additional screens, each representing a different camera.

The primary camera is a first-person point of view, which, with one exception, is perceived as a single continuous shot. Inspired by films such as Alexander Sokurov's Russian Ark (2003) and Chantal Akerman's Hôtel Monterey (1973), long tracking shots are used to move the viewer through a continuous, uninterrupted experience of the lighthouse. Exploring the areas in which filmmaking and games design intersect, the first-person point of view is reminiscent of games and virtual reality experiences in which participants, immersed, often experience a greater degree of agency in the virtual world around them.

The secondary cameras are located in various, often aerial, positions and track the primary camera as it moves through the rooms. In traditional filmmaking, the single-take film is technically demanding and achieved via steady-cam, drone, or dolly shots. Within a game engine, virtual cameras can create the same result with relative ease. In Grace, a number of cameras, virtual dolly carts, and tracks were positioned throughout the space enabling for logistically complex single shots, such as moving across the sea and into the lighthouse. Virtual cameras, just as their physical counterparts, provide the ability to control camera type, aperture, and ISO. Post-processing effects such as colour and grain, among many others, can be added directly within the game engine, which bypasses the need for external editing software.

Recent advances in game engines present an exciting medium for realistic world-building and filmmaking. From lighting to framing, Grace adopted many traditional filmmaking techniques, whilst taking advantage of the freedom and flexibility presented by computer-generated filmmaking.

\section{REFERENCES}

Armstrong, R. (1965) Grace Darling: Maid and Myth. J. M. Dent and Sons, London.

Cunningham, H. (2007) Grace Darling. Hambledon Continuum, London.

Darling, T. (1880) Grace Darling: Her True Story. From Unpublished Papers in Possession of Her Family. Hamilton, Adams \& Co., London.

Mitford, J. (1989) Grace Had an English Heart. E. P. Dutton, New York. 